\title{
KONFLIK SOSIAL DALAM NOVEL KOBARAN CINTAKU KARYA RATNA SARUMPAET
}

\author{
Alfarissy Vega Husaini Putera \\ SMK Pelayaran Wira Maritim \\ Jl. Raya Kuwukan no 2 Sambikerep, Surabaya, Indonesia \\ Pos-el : alfarissyvega1@gmail.com
}

\begin{abstract}
This research study analysis in the form of better about social unrest in a novel Kobaran Cintaku. In assessing novel Kobaran Cintaku researchers used qualitative research methods of analyzing the form of descriptive, description not be the number or coefficient about the relationship between variables. The conflict contained in the novel Kobaran Cintaku: the first conflict between fellow individuals. Conflict strife of different opinions. The second conflict between individuals and group of torture and kidnapping. The third the conflict between fellow group in conflict oppression and war.
\end{abstract}

Keywords : conflict, social

\begin{abstract}
Abstrak
Penelitian ini berupa kajian lebih mendalam tentang analisis konflik sosial dalam novel Kobaran Cintaku. Dalam mengkaji novel Kobaran Cintaku ini peneliti menggunakan metode penelitian kualitatif deskriptif yaitu menganalisis bentuk deskripsi, tidak berupa angka atau koefisien tentang hubungan antar variabel. Bentuk konflik yang terdapat dalam novel Kobaran Cintaku adalah: yang pertama konflik antar sesama individu. Konflik perselisihan yang berupa beda pendapat. Yang kedua konflik antara individu dan kelompok berupa penyiksaan dan penculikan. Yang ketiga ialah konflik antar sesama kelompok dalam konflik penindasan dan peperangan.
\end{abstract}

Kata Kunci : Konflik, Sosial 


\section{PENDAHULUAN}

Karya sastra merupakan hasil cipta, rasa dan karsa manusia, selain memberikan hiburan juga sarat dengan nilai, baik nilai keindahan maupun nilai- nilai ajaran hidup. Orang dapat mengetahui nilai-nilai hidup, susunan adat istiadat, suatu keyakinan, dan pandangan hidup orang lain atau masyarakat melalui karya sastra. Dengan hadirnya karya sastra yang membicarakan persoalan manusia, antara karya sastra dengan manusia memiliki hubungan yang tidak terpisahkan. Sastra dengan segala ekspresinya merupakan pencerminan dari kehidupan manusia. Permasalahan dalam kehidupan manusia, merupakan ilham bagi pengarang untuk mengungkapkan dirinya dengan media karya sastra.

Memang suatu hal yang tidak dapat dipungkiri bahwa seorang pengarang senantiasa dipengaruhi oleh ruang dan waktu. Setiap pengarang pasti tidak hidup dalam ruang yang hampa, tetapi dinamis dan kompleks sehingga hasil sebuah karya sastra bukanlah berdiri sendiri (otonom), melainkan sesuatu yang terikat erat dengan situasi dan kondisi lingkungan tempat karya itu dilahirkan. Hal itu pula yang sekiranya melatar belakangi Ratna Sarumpaet dalam kemunculan novelnya Kobaran Cintaku.

Kerusuhan Maluku pernah menjadi episode kelam perjalanan negeri ini. Peristiwa yang terjadi dalam kurun Januari hingga Desember 1999 tersebut bahkan mencatat banyak korban di masyarakat. Pelanggaran HAM banyak terjadi dalam peristiwa tersebut. Untuk menggali kembali apa yang sebenarnya terjadi pada saat itu, Ratna Sarumpaet menulis novel "Kobaran Cintaku: Maluku Baku Bae". Ratna melakukan penelitian dan menuliskan novel tersebut dalam kurun waktu dua tahun.
Ratna Sarumpaet adalah seniman Indonesia yang banyak mengeluti dunia panggung teater, selain sebagai aktivis organisasi sosial dengan mendirikan Ratna Sarumpaet Crisis Centre. Ratna terkenal dengan pementasan monolog Marsinah Menggugat. Ratna Sarumpaet sempat menempuh kuliah di Fakultas Teknik Arsitektur dan Fakultas Hukum UKI, Ratna memilih kesenian sebagai alat perjuangannya. Keberpihakannya pada orang-orang kecil dan marginal menjadi tema setiap karya yang dilahirkannya yang mengupas secara terbuka masalah-masalah kemanusiaan, kebenaran dan keadilan serta mempertanyakannya secara frontal ke hadapan pemerintah. Dalam lima belas tahun terakhir, di tengah kesibukannya sebagai aktivis HAM dan kemanusiaan, Ratna telah menghasilkan sembilan naskah drama, yang membuatnya dikenal dalam bidangnya. Seluruh naskah itu ditulis untuk memprotes adanya tindak ketidakadilan dalam pemerintahan yang cenderung menindas kaum kecil dan kelompok minoritas. Semua naskah 
disutradarainya sendiri dan diproduksi/ dipentaskan kelompok drama Satu Merah Panggung, yang didirikannya 1974.

Ratna Sarumpaet dikenal sebagai aktivitis Hak Asasi Manusia (HAM). Di tengah nuansa dan perayaan Hari HAM Sedunia, Ratna meluncurkan novelnya bertajuk Kobaran Cintaku yang menceritakan pelanggaran HAM dalam konflik di Maluku. Selama dua tahun Ratna keluar masuk kampung halamannya di Maluku untuk melakukan penelitian dan menulis novelnya. Tanpa sedikitpun berniat untuk kembali menguak luka lama, Ratna ingin buku ini sebagai pelajaran dan membuka mata masyarakat bahwa pernah terjadi kisah kelam di tanah Maluku, tanah ia dibesarkan.

Melalui karya sastra yang dalam hal ini ialah novel, penyampaian konflik sosial dinilai efektif karena karya sastra dapat dinikmati oleh semua karangan sehingga masyarakat diharapkan dapat mengambil pesan dari bacaan tersebut. Dengan kata lain, Novel dapat memberikan pencerahan ataupun pemikiran baru terhadap pembacanya sehingga nilai dari karya sastra yang mengandung unsur keindahan dan akan tercapai. Tentu saja dengan adanya penelitian konflik sosial ini sangat diharapkan kehidupan sosial masyarakat pada umumnya dan masyarakat Maluku khususnya akan jauh lebih baik dan harmonis.

Dari fenomena itulah, peneliti memutuskan untuk melakukan kajian lebih mendalam lagi tentang analisis konflik sosial dalam novel Kobaran Cintaku. Penelitian mengenai konflik sosial pada umumnya sudah pernah dilakukan. Namun analisis konflik sosial dalam novel Kobaran Cintaku belum pernah dilakukan sebelumnya.

\section{METODE PENELITIAN}

Metode penelitian merupakan cara yang digunakan oleh peneliti untuk mencapai tujuan yakni untuk mencapai pokok permasalahan dari penelitian yang dilakukan. Penelitian ini menggunakan metode penelitian kualitatif, karena permasalahan yang muncul belum jelas, holistik, kompleks, dinamis dan penuh makna sehingga tidak mungkin data pada situasi sosial tersebut dijaring dengan metode penelitian kuantitatif dengan instrumen seperti tes, kuesioner, pedoman wawancara. Selain itu peneliti bermaksud untuk memahami situasi sosial secara mendalam, menemukan pola, hipotesis dan teori.

Metode kualitatif adalah metode pengkajian terhadap suatu masalah yang tidak didesain atau dirancang menggunakan prosedur-prosedur statistik. Dalam mengkaji novel Kobaran Cintaku ini peneliti menggunakan metode penelitian kualitatif deskriptif yaitu menganalisis bentuk deskripsi, tidak berupa angka atau koefisien tentang hubungan antar variabel.

Sumber data adalah subjek penelitian dari mana data diperoleh. Sumber data penelitian ini adalah sumber data primer yakni novel Kobaran Cintaku karya Ratna Sarumpaet, yang diterbitkan oleh Noura Books (PT.Mizan Publika) Edisi revisi dari novel Maluku 
Kobaran Cintaku (2010), cetakan pertama, Desember 2014, dengan tebal 419 halaman. Sampul depan novel ini terdapat desain cover dan ilustrasi cover karya Fahmi Ilmansyah warna dasar sampul novel ini adalah warna putih dan merah, terdapat gambar pita merah yang berbentuk seperti hati. Di bagian atas terdapat nama penulis Ratna Sarumpaet. Dibagian bawah kanan terdapat tulisan "Maluku Baku Bae" beserta dengan komentar dari Aktor berdarah Maluku Reza Rahadian. Novel ini patut untuk diteliti karena kasus yang diungkap oleh pengarang merupakan sebuah realita sosial yang sesungguhnya terjadi pada saat ini, sehingga penelitian ini diharapkan dapat membawa perubahan ke arah yang lebih baik.

Data primer dalam penelitian ini yaitu berupa kata-kata dan kalimatkalimat yang dikutip dalam novel Kobaran Cintaku Karya Ratna Sarumpaet, yang menunjukkan konflik sosial yang terjadi pada diri tokoh yang sesuai dengan rumusan masalah. Sedangkan data sekunder dalam penelitian ini terdiri atas beberapa buku panduan sosiologi sastra, serta buku-buku penunjuang lain yang berkaitan dengan teori yang digunakan dalam penelitian.

Objek penelitian merupakan sasaran utama dalam pembahasan sebuah penelitian. Sesuai dengan rumusan masalah penelitian, maka objek penelitian ini adalah konflik sosial yang terdapat dalam novel Kobaran Cintaku karya Ratna Sarumpaet. Hal ini dikarenakan novel tersebut menyuguhkan gambaran konflik sosial yang kuat

\section{HASIL DAN PEMBAHASAN}

Penelitian yang berjudul Konflik Sosial dalam Novel Kobaran Cintaku karya Ratna Sarumpaet (Kajian Sosiologi Sastra) ini memiliki dua rumusan masalah yakni, yang pertama mengkaji mengenai karakter tokoh dalam novel Kobaran Cintaku yang mempengaruhi timbulnya konflik sosial dan yang kedua membahas mengenai bentuk konflik sosial yang terjadi dalam novel Kobaran Cintaku dari perspektif sosiologi karya sastra beserta cara mengatasi konflik sosial tersebut. Adapun teori yang digunakan untuk menjawab rumusan masalah tersebut ialah terdiri dari teori tokoh dan penokohan dari Burhan Nurgiyantoro (2009) dalam Teori Pengkajian Fiksi dan teori konflik sosial Lewis A. Coser (2009) yang dipadukan dengan strategis mengatasi konflik Dean G. Pruitt dan Jeffry Z. Rubin (2009) dalam Teori Konflik Sosial.

Masalah sosial mungkin tidak akan terjadi jika yang kuat bersedia berkorban untuk yang lemah atau mau berkompromi. Masalah sosial justru akan timbul ketika yang kuat menggunakan kekuatannya untuk membela kepentingannya. Dalam kenyataan itulah konflik sosial tidak dapat dihindari dari kehidupan manusia sebagai makhluk sosial yang saling berinteraksi satu sama lain. Ditinjau dari jenis konflik berdasarkan ruang lingkup atau tipe perubahan yang 
menstimulasinya, Coser membagi atas realis dan nonrealis. Konflik realistis memilik sumber yang konkret atau bersifat materil, seperti perebutan sumber ekonomi dan wilayah. Sedangkan konflik non realistis didorong oleh keinginan yang tidak rasional dan cenderung bersifat ideologis sedangkan jika ditinjau berdasarkan tempat terjadinya, Coser membagi atas dua bentuk konflik yakni konflik in group dan konflik out group (Susan, 2010:60). Dalam novel Kobaran Cintaku, konflik realis menjadi masalah utama yang diungkapkan pengarang, dan terjadinya konflik tersebut tidak terlepas pada konflik in group maupun out group.

Novel Kobaran Cintaku berlatar lokasi di tanah Maluku, lokasi yang sering terjadi peperangan antar suku dan saudara. Kobaran Cintaku mengisahkan perjalanan cinta, ras, dan perjuangan. Yang menarik dari novel ini ialah seorang wanita yang memperjuangkan cinta beda agama dan terpojok di situasi yang memanas. Namun setiap kisahnya sangat menarik. Seolah-olah pembaca diajak ke tanah Maluku yang hirukpikuk dengan peperangan yang tak berujung.

Perilaku antarmanusia pun disindir secara satir dalam novel ini. Mey dan Ali yang saling mencinta tapi berbeda agama. Kisah Meylani yang pernah menjadi relawan waktu perang di A.Y Patty. Perang yang terjadi akibat hal sepele masalah Ras dan Politik di Maluku.

Maluku atau yang dikenal secara internasional sebagai Moluccas dan
Molukken adalah provinsi tertua yang ada di Indonesia, lintasan sejarah Maluku telah dimulai sejak zaman kerajaan-kerajaan besar di Timur Tengah seperti kerajaan Mesir yang dipimpin Firaun. Bukti bahwa sejarah Maluku adalah yang tertua di Indonesia adalah catatan tablet tanah liat yang ditemukan di Persia, Mesopotamia, dan Mesir menyebutkan adanya negeri dari timur yang sangat kaya, merupakan tanah surga, dengan hasil alam berupa cengkeh, emas dan mutiara, daerah itu tak lain dan tak bukan adalah tanah Maluku yang memang merupakan sentra penghasil Pala, Fuli, Cengkeh dan Mutiara. Pala dan Fuli dengan mudah didapat dari Kepulauan Banda, Cengkeh dengan mudah ditemui di negeri-negeri di Ambon, Pulau-Pulau Lease (Saparua, Haruku\&Nusa laut) dan Nusa Ina serta Mutiara dihasilkan dalam jumlah yang cukup besar di Kota Dobo, Kepulauan Aru.

Ibu kota Maluku adalah Ambon yang bergelar atau memiliki julukan sebagai Ambon Manise, kota Ambon berdiri di bagian selatan dari Pulau Ambon yaitu di jazirah Leitimur. Ada wacana bahwa Kota Ambon Manise sudah semakin padat dan tidak lagi layak untuk menampung jumlah penduduk yang dari tahun ke tahun meningkat tajam yang merupakan ibu kota Provinsi akan menjadi kota biasa karena ibu kota direncanakan pindah ke negeri Makariki di Kabupaten Maluku Tengah.

Jumlah penduduk provinsi ini tahun 2010 dalam hasil sensus 
berjumlah 1.533 .506 jiwa. Maluku terletak di Indonesia Bagian Timur. Berbatasan langsung dengan Maluku Utara dan Papua Barat di sebelah utara, Laut Maluku, Sulawesi Tengah, dan Sulawesi Tenggara di sebelah barat, Laut Banda, Timor Leste, dan Nusa Tenggara Timur di sebelah selatan serta Laut Aru dan Papua di sebelah timur.

Maluku memiliki 2 agama utama yaitu agama Islam Sunni yang dianut $50,8 \%$ penduduk Maluku dan agama Kristen (baik Protestan maupun Katolik) yang dianut $48,4 \%$ penduduk Maluku. Maluku tercatat dalam ingatan sejarah dunia karena konflik atau tragedi krisis kemanusiaan dan konflik horizontal antara basudara Salam-Sarane atau antara Islam dan Kristen yang lebih dikenal sebagai Tragedi Ambon. Selepas tahun 2002, Maluku berubah wajah menjadi provinsi yang ramah dan damai di Indonesia, untuk itu dunia memberikan suatu tanda penghargaan berupa Gong Perdamaian Dunia yang diletakkan di ACC (Ambon City Centre).

Pada tahun 1999 ketika konflik atau tragedi krisis kemanusiaan dan konflik horizontal antara basudara SalamSarane atau antara Islam dan Kristen yang lebih dikenal sebagai Tragedi Ambon melanda Maluku, sebagian wilayah Provinsi Maluku dimekarkan menjadi Provinsi Maluku Utara, dengan ibu kota di Sofifi. Namun, karena Kota Sofifi dinilai belum siap menjadi ibu kota maka pusat pemerintahan sementara sampai 2009 berada di Kota Ternate yang berada di Pulau Ternate.
Provinsi Maluku dan Maluku Utara membentuk suatu gugus-gugus kepulauan yang terbesar di Indonesia dikenal dengan Kepulauan Maluku dengan lebih dari 4.000 pulau baik pulau besar maupun kecil.

Sastrawan sekaligus penulis buku, Ratna Sarumpaet, meluncurkan novel berjudul "Maluku Kobaran Cintaku" dalam satu acara yang digelar di pelataran monumen Gong Perdamaian Kota Ambon "Novel Maluku Kobaran Cintaku saya persembahkan untuk rakyat Maluku bertepatan dengan peringatan hari Hak Azasi Manusia Internasional,"kata Ratna. Ide menulis novel itu muncul dari keinginannya memperkenalkan Maluku kepada dunia dan penegasan bahwa konflik sosial yang melanda daerah ini pada 19992003 tidak boleh terjadi di belahan dunia manapun.

Rakyat Maluku hidup dengan budaya dan agama beragam. Ratusan tahun, nilai-nilai budaya Pela Gandong merajut pergaulan sosial mereka dalam kerukunan yang toleran, hangat, dan saling menjaga. Maka, ketika oleh sebuah pertengkaran sepele antara sopir angkot dan seorang penumpang, konflik antaragama tiba-tiba pecah, berdarah, dan dalam waktu singkat meluas (1999-2003), dunia terenyak dan sulit percaya.

Berkisah tentang bagaimana sekelompok intelektual muda (Ali, Mey, Melky, Ridwan, dll.) dalam menolong korban dan menyerukan damai, 
bagaimana mereka dimusuhi dan diintimidasi oleh pihak-pihak bertikai termasuk aparat; mengikuti dengan pedih pertarungan Ali dan Mey (cucu dari dua tokoh agama terkemuka) dalam mempertahankan cinta (terlarang) mereka; memahami betapa pertikaian antar agama mampu mengoyak nalar, melumpuhkan akal sehat, dan mengobarkan api kebencian; novel ini akan membuka mata pembaca, betapa kerusuhan Maluku yang selama ini diasumsikan sebagai konflik horisontal antar umat Islam dan Kristen, sesungguhnya memiliki kompleksitas yang hingga hari ini belum kunjung terungkap

"Dari Monumen Gong perdamaian ini dan melalui novel Maluku Kobaran Cintaku, saya ingin mengatakan kepada dunia bahwa peradaban manusia jangan dikoyakkoyak hanya demi kepentingan sesaat," kata Ratna Sarumpaet. Novel setebal 512 halaman yang diterbitkan oleh Komodo Books tersebut mengisahkan sekelompok anak muda (Mey, Aly, Melky Ridwan, Peter dan Aisah) yang terjebak dalam konflik yang menggerus kerukunan antarsuku dan agama.

"Sebuah sejarah jangan dilupakan bahwa kepentingan segelintir orang mampu merobek tatanan hidup orang basudara Kristen dan Islam yang dikenal dengan sebutan Pela dan Gandong itu." ujarnya. Dalam novelnya itu, Sarumpaet menghadirkan sosok generasi muda Maluku yang tidak ingin Pela Gandong terkoyak dan bertekad terus menyuarakan damai, kendati harus berhadapan dengan kelompokkelompok yang tidak menginginkan perdamaian. "Saya ingin mengatakan dalam novel ini tentang pentingnya manusia saling menghormati, tidak peduli apapun agama, ras da sukunya. Ini bukan soal siapa menang dan siapa kalah tetapi soal moral dan nilai kemanusian," kata pegiat HAM ini.

Setelah itu, novel Maluku Kobaran Cintaku juga akan dicetak dalam beberapa versi bahasa dan diluncurkan di Belanda pada Juli 2011. "Jadi buku ini bukan lagi menjadi milik orang Maluku dan Indonesia. Dengan membaca buku ini dunia akan mengetahui bahwa Maluku itu memiliki budaya Pela dan Gandong yang tidak bisa dipisahkan oleh kepentingan apapun," tandasnya.

Novel tersebut juga akan dibagikan ke perpustakaan sekolah untuk dijadikan bahan bacaan siswa. Peluncuran novel dihadiri Gubernur Maluku Karel Albert Ralahalu yang menyatakan Pemprov Maluku menyambut baik peluncuran novel tersebut sebagai sebuah mahakarya di penghujung tahun 2010.

"Dari Gong perdamian ini, saya mengajak masyarakat Maluku untuk berkomitmen untuk lebih merekatkan hubungan persaudaraan dalam bingkai Pela dan Gandong," kata Ralahalu. Pada kesempatan tersebut, bintang iklan salah satu merk sabun terkena, Atika Hasiholan, yang juga putri Ratna Sarumpaet, bersama Jajang C Noer, wartawan senior Rudy Fofid dan sejumlah pemuda turut membacakan 
penggalan cerita dari Novel tersebut kepada warga kota yang memadati pelataran Gong perdamaian. Sebelum acara peluncuran, dilakukan bedah novel karya Ratna tersebut, dengan pembicara termasuk Tony Pariela dari Universitas Pattimura.

Penokohan

Kehadiran tokoh dinilai sebagai sesuatu yang sangat berpengaruh dalam memahami sebuah cerita. Tokoh cerita menempati posisi strategis sebagai pembawa dan penyampai pesan, amanat, moral, atau sesuatu yang sengaja ingin disampaikan kepada pembaca, begitu pula dalam memahami novel Kobaran Cintaku. Istilah "penokohan" mencakup masalah siapa tokoh cerita, bagaimana perwatakan, dan bagaimana penempatan, dan pelukisnya dalam sebuah cerita, sehingga sanggup memberikan gambaran yang jelas kepada pembaca (Nurgiyantoro, 2009: 166). Selain itu dalam prosa fiksi tokoh dihadirkan dengan keterkaitan yang kuat dengan konflik. Ada tokoh membawa prinsipil, ada tokoh yang memiliki kecenderungan menentang, dan adapula tokoh yang cenderung sebagai pendamai (Najid, 2009:28)

Analisis karakter ini bertujuan untuk mengetahui siapa sajakah tokoh dalam novel Kobaran Cintaku yang menjadi penyebab timbulnya konflik sosial dan mengetahui seluruh tokoh yang terlibat dalam situasi konflik sosial tersebut. Dari masing masing karakter tokoh yang telah dianalisis maka akan nampak tokoh yang cenderung menjadi pihak penyulut konflik dalam kehidupan masyarakat Maluku dalam bingkai Kobaran Cintaku. Jadi, untuk mengetahui bentuk-bentuk konflik yamg terjadi, perlu adanya pemahaman karakter tokoh yang terdapat dalam novel Kobaran Cintaku.

Dalam novel Kobaran Cintaku, tokoh yang dihadirkan pengarang adalah sebuah keluarga yakni Meynar, Ali, dan Melki. Selain itu, adapula tokoh tambahan yakni Stella, Aisah, Andre. Adapun tokoh yang timbul dan mempengaruhi timbulnya konflik ialah kehadiran tokoh antagonis yaitu Riyan.

\section{Bentuk konflik sosial dan solusi mengatasi konflik}

Sebagai makhluk sosial, manusia selalu berinteraksi dengan sesama manusia lainnya, baik dalam lingkungan keluarga ataupun masyarakat luas. Ketika berinteraksi dengan sesamanya, maka akan selalu diwarnai dua hal, yaitu konflik dan kerjasama. Konflik merupakan bentuk interaksi dimana tempat, waktu, serta intensitas dan lain sebagainya tunduk pada perubahan (Poloma, 2010:107). Konflik sosial bisa diartikan sebagai perjuangan untuk mendapatkan nilainilai atau pengakuan status, kekuasaan dan sumber daya langka. Sehingga tidak dapat dipungkiri bahwa konflik merupakan bagian dari kehidupan manusia. 
Konflik dapat menjadi penyebab atau pengubah kepentingan kelompok kelompok, organisasi, kesatuan, dan lain sebagainya. Hal ini kemudian menimbulkan kebencian, kecemburuan yang kemudian akhirnya menjadi faktor penyebab terjadinya konflik (Affandi, 2004: 136). Seperti halnya yang terjadi pada kisah dalam novel karya Ratna Sarumpaet novel Kobaran Cintaku yang mengisahkan tentang mempertahankan cinta mereka yang beda agama. Pertikaian antar agama mampu mengoyak nalar, melumpuhkan akal sehat. Kerusuhan yang terjadi di tanah Maluku yang selama ini diasumsikan sebagai konflik horizontal antar umat Islam dan Kristen, sesungguhnya memiliki kompleksitas yang hingga hari ini belum kunjung terungkap.

Namun pertikaian antar umat Kristen dan Islam yang terjadi di Maluku, mau tak mau ikut mempengaruhi hubungan baik yang sudah terjalin antara kedua keluarga ini, Mey cucu Pendeta Bram yang menjalin kasih dengan cucu dari Tuang Abu Bakar yang bernama Ali, mulai meragukan hubungannya. Mey yang aktif dan idealis, mempertanyakan letak kesalahan dari sebuah perbedaan. Perbedaan dari keyakinan yang ia dan Ali anut. Ditengah kekacauan yang terjadi di tanah kelahiran yang mereka cintai bersama, Tuang Abu Bakar dan Pendeta Bram tetap bersatu dan berjuang untuk meredam pertikaian antar umat beragama yang terjadi, mereka sepakat bahwa peristiwa ini terjadi akibat adanya provokasi dari pihak luar, dan masyarakat Maluku hanyalah korban.
Konflik semakin menjadi ketika Masjid Al Hidayah tempat dimana Tuang Abu Bakar sedang melakukan ibadah beserta puluhan jemaahnya di bom oleh oknum yang tak diketahui. Peristiwa ini menyebabkan tewasnya Tuang Abu Bakar beserta 20 jemaah lainnya. Sebuah pukulan yang luar biasa bagi Ali dan keluarganya, juga Pendeta Bram dan keluarga sebagai sahabat karibnya selama bertahuntahun, terbayang bagaimana usaha mereka untuk membangun kerukunan antar umat Kristen dan Islam seolah menjadi kesia-siaan belaka. Belum lagi kekerasan yang dialami oleh Ali, dan Melky yang tak lain adalah kakak kandung Mey, mereka disiksa kemudian dibuang begitu saja oleh sekelompok orang yang tak dikenal. Mey pun mengalami hal yang sama, mereka menangkap Mey dan menyekapnya di sebuah gudang.

Hal ini dikarenakan organisasi PMBB (Pemuda Maluku Baku Bae), yang mereka bentuk bersama. Adegan yang cukup dramatis bisa kita temui pada bagian akhir novel ini. Bagaimana perjuangan Mey, Ali, Melky serta beberapa orang sahabat-sahabatnya dalam mempertahankan keutuhan dan kedamaian di bumi Maluku, hingga menyebabkan tewasnya rekan mereka Ahmad dan Pieter, yang kemudian dijadikan sebagai simbol perjuangan mereka. Lebih dari tujuh ribu nyawa terenggut selama empat belas bulan kerusuhan terjadi. Pada beberapa peristiwa, penguburan massal pun tak terhindarkan, Namun pemakaman Ahmad dan Pieter adalah pemakaman paling dramatis dan berduka yang 
pernah terjadi. Air mata untuk semua korban yang mati seolah tumpah di pemakaman dua tokoh muda itu. Berlangsung di hari yang berbeda dan di pemakaman yang terpisah jauh, Ahmad di pemakaman Islam di Ambon dan Pieter di Seram di sebuah pemakaman Kristen, masyarakat dari dua agama yang bertikai berbaur menghormati kedua jenazah itu dalam iring-iringan yang memanjang hingga ratusan meter.

\section{SIMPULAN}

Penelitian yang berjudul Konflik Sosial dalam Novel Kobaran Cintaku karya Ratna Sarumpaet: Kajian Sosiologi Sastra ini menganalisis mengenai karakter tokoh yang mempengaruhi timbulnya konflik sosial dan menganalisis pula bentuk bentuk konflik sosial yang terjadi di dalamnya dari perspektif sosiologi karya sastra beserta cara mengatasi konflik sosial tersebut. Adapun bentuk konflik yang terdapat dalam novel Kobaran Cintaku adalah: yang pertama konflik antar sesama individu. Konflik perselisihan yang berupa beda pendapat. Yang kedua konflik antara individu dan kelompok berupa penyiksaan dan penculikan. Yang ketiga ialah konflik antar sesama kelompok dalam konflik penindasan dan peperangan.

\section{DAFTAR PUSTAKA}

Affandi, Hakimul Ikhwan. 2004. Akar Konflik Sepanjang Zaman. Yogyakarta : Pustaka Pelajar.

Coser, Lewis A. 2009. Sosiologi Konflik dan Isu-isu Konflik Kontemporer. Jakarta : Gramedia.

Najid, Moh. 2009. Mengenal Apresiasi Prosa Fiksi. Surabaya : Kreasi Media.

Nurgiyantoro, Burhan. 2009. Teori

Pengkajian Fiksi. Yogyakarta : Gadjah Mada.

Poloma, Margaret. 2010. Sosiologi

Kontemporer. Jakarta : Grafindo Persada

Pruitt, Dean G \& Jeffry Z Rubin. 2009. Teori Konflik Sosial. Yogyakarta : Pustaka Pelajar.

Sarumpaet, Ratna. 2014. Kobaran

Cintaku. Jakarta : Noura Books.

Susan, Novri. 2010. Pengantar Sosiologi Konflik. Jakarta : Kencana. 